\title{
Evaluation Implementation Curriculum 2013
}

\author{
Ihsana El Khuluqo ${ }^{1 \text { a) }}$ Istaryatiningtias ${ }^{2 b)}$ Eva Syarifah $^{3 \mathrm{c})}$ \\ ${ }^{1}$ Sekolah Pascasarjana Universitas Muhammadiyah Prof. DR. HAMKA \\ Jl. Warung Jati Barat, No.17 Kalibata, Kec. Pancoran, Kota Jakarta Selatan, 12740 \\ ${ }^{2}$ Sekolah Pascasarjana Universitas Muhammadiyah Prof. DR. HAMKA \\ Jl. Warung Jati Barat, No.17 Kalibata, Kec. Pancoran, Kota Jakarta Selatan, 12740 \\ ${ }^{3}$ MI Al Khairiyah Mampang Prapatan \\ Jl. Mampang Prapatan IV No.71,Mampang Prpt., Kota Jakarta Selatan, 12790
}

a) $\frac{\text { ihsana_khuluqo@uhamka.ac.id }}{\text { b) iis_ningtias@uhamka.ac.id }}$
${ }^{c)}$ esyarifah78@gmail.com

\begin{abstract}
This reseach aims to reveal the results of the implementation of the 2013 Curriculum by using the descriptive qualitative method with CIPP model (context, input, process, product). The method that is by getting data scientifically, including collecting data using observation, structured interviews and documentation. The interview was conducted with Headmaster student affairs representative Head of administration, Teachers, School Committee, Parents, and Students. Based on the results of this study it can be concluded that The context in the implementation of the 2013 curriculum is clear in its vision, mission, goals, programs. Inputs in the implementation of the 2013 curriculum were seen by a number of teachers and employees whose educational background did not match the subjects they have. The process of implementing the 2013 curriculum has not yet shown the expected results. This can be seen from the scientific approach implemented in the learning process, the application of GLS, the preparation of instruments and rubric assessments, the preparation of questions based on HOT Skills have not been maximum. The product in the implementation of the 2013 curriculum has run well according to the procedure although it has not been optimal, both in terms of students and teachers. The obstacles in the implementation of the 2013 curriculum includes constraints originating from the government, teachers, institutions, students, and parents. The strategy to overcome these obstacles is by improving the quality of school management. It is expected that institutions will improve the school management system so that the implementation of the 2013 curriculum is able to show optimal results.
\end{abstract}

Keywords. Education, Indonesia curriculum.

\section{INTRODUCTION}

The term Curriculum comes from the Greek curir, meaning runner or curure meaning place to race. Curriculum means the distance that a runner must travel from start to finish in order to be awarded [1]. Curriculum is a set of plans containing experiences that students will achieve under the guidance of educators [2]. So that it can be concluded curriculum is a set of learning activity plans containing objectives, content, and materials / subject matter that will be a reference in providing learning experience for students, providing skills, knowledge, and character training of students.

Curriculum Reform aims to improve the quality of education of a nation that boils down to improving the quality of national education. That change is in order to shape students into intelligent, moral, sincere, creative, communicative, and tolerant in different lives. Pisa and TIMSS results influenced the education policies of 
many Countries. The results of the TIMSS and PISA studies of our students were only able to level three out of six levels of cognitive abilities related to high levels of thinking ability. therefore, a curriculum that fits the needs of the community and follows the phenomenon of a dynamic and ever-changing society. Education and Culture ministry has always made changes to the curriculum and adapts to current needs with the aim of improving the competitiveness of human resources in Indonesia. It is intended to increase the competitiveness of human resources in Indonesia.

Academics and practitioners think that the curriculum must be continuously updated to match the demands of the times and technological advances [3]. But often educators are closed to changes related to the curriculum because adjustments are needed from the previous curriculum [4]. Related, curriculum adjustment, educators must identify what skills and knowledge children need to be literate in the digital era. Thanks to its interactive and creative features, the internet has enabled users not only to become consumers but also producers of information [5-6].

Curriculum evaluation cannot be limited to student learning, but includes all factors curriculum system and the entire curriculum practice process as what is evaluated systematically to some extent [7-8]. Curriculum evaluation should focus on process and products produced from the curriculum, such as curriculum syllabi, curriculum teaching resources and materials, teaching plans, classroom teaching performance and examination papers. As a result, evaluation can provide very effective benefits for the smooth running of the learning process that will come [9]. [10] after classified curriculum evaluation can be divided into two types: 1) Static curriculum content evaluation of curriculum plans, curriculum materials and student learning outcomes. 2) Focus on dynamic curriculum content process and curriculum effects. Beigi, Keramatib and Ahmadi (2011) found six factors in evaluating the curriculum, namely objectives, content of the curriculum and structural characteristics, student freedom, characteristics of a professional teacher, student learning time. In addition, the evaluation of the curriculum can fulfill information needs in the decision making process. in every instance [11].

Curriculum 2013 is the current curriculum in the world of education in Indonesia in lieu of the 2006 Unit of Education (KTSP) Level Curriculum and has been in effect since 2014. In the implementation of curriculum 2013, evaluation is one of the important components and stages that must be taken by teachers to know the effectiveness of the curriculum. Evaluation becomes part of management, namely planning, organization, implementation, monitoring, and evaluation. Without an evaluation, we will not be able to know how the condition of the curriculum is in the design, implementation, and results.

The demand for quality human resources should be offset by improvements in education. One of the important elements of education that must always be improved is the curriculum. The curriculum should evolve according to the demands of the times. Curriculum changes are an effort by the government to improve the quality of education. [12] Oemar states that curriculum changes should look to future needs, reemphase the original form, stop the practice of errors in the application of the old curriculum and provide better alternative solutions. Change means fixing, perfecting by making something wrong right.

The 2013 curriculum, which has been in effect nationwide since 2014, continues to be in the spotlight and has received widespread criticism. Especially when it comes to implementation that is judged to still be many shortcomings. Researchers from Universitas Sebelas Maret (UNS) Surakarta noticed eight problems that caused the implementation of the curriculum to be less optimal. The eight problems found were directly related to teachers, among others; the difficulty of changing the mindset of teachers, low reading culture, low culture of researching, lack of mastery of IT, weak mastery of the field of administration and teachers emphasize more judgment on cognitive aspects only. The eight issues are an obstacle in the implementation of the 2013 curriculum itself. In addition to these problems, the absence of a thorough evaluation of the implementation of the 2013 curriculum is also the cause of the not optimal implementation of curriculum 2013. Teacher unpreparedness was a major factor in inhibiting the implementation of curriculum 2013. Because departing from the teacher's infahension about curriculum implementation 2013 caused them not to carry out a series of processes in the implementation of the 2013 Curriculum itself, both in its planning, implementation, and assessment.

In kemdikbud regulation [13] it is explained that the evaluation of the 2013 Curriculum is carried out during the period of deliberation process, design development, and curriculum documents, and during the implementation period of the curriculum. Evaluation in the development of ideas aims to produce improvements in the concepts of the desired curriculum. Evaluation in curriculum implementation is carried out with the aim of identifying obstacles and problems that arise in the implementation of the curriculum so as to help principals and teachers to solve the problem. Evaluations are carried out on each unit of education on a regular basis and take turns. Evaluation results are used as consideration materials to improve curriculum weaknesses to be more effective in the future. 


\section{METHOD}

The research method used in the study on Evaluation of Curriculum Implementation 2013 at Madrasah Ibtidaiyah Al Khairiyah Pagi is a method of qualitative evaluation. According to Lexy J. Moleong [14], that qualitative research is rooted in natural background as wholeness, relying on humans as a research tool, utilizing qualitative methods, conducting data analysis inductively, directing its research objectives to find basic theories, descriptive, more concerned with processes than results, limiting studies with focus, having a set of criteria for examining the validity of data, the design of the research is temporary, and the results of the study are agreed upon by both the researchers and the research subjects.

Qualitative evaluation methods are used in this study because the formulation of this research issue emphasizes more on giving consideration about the value and meaning of the implementation of curriculum 2013. Because the data taken relates to a holistic and meaningful social environment, this method is a great alternative. In addition to these reasons, researchers also have some considerations. First, qualitative evaluiasi methods are easier to use to observe social situations. Second, this method presents directly the relationship between evaluators and respondents. Third, this method is more sensitive and able to adjust to the many influences on the patterns of values encountered.

As for the CIPP evaluation model chosen because first, the purpose of this model is to create a framework to evaluate planning. Second, this model emphasizes the evaluation of the implementation of learning in the classroom. Third, this model encourages evaluators to use a variety of standards in evaluating the curriculum so that views of the curriculum can be widely reviewed. Fourth, the CIPP model emphasizes the evaluation of the implementation of learning thoroughly, not only limited to changes in the behavior of students but also on all the components that are influential in the implementation of learning. The CIPP model is an evaluation model oriented towards decision makers. Muryadi [15] and Sukardi [16] in his book explains that the evaluation of cipp model on its outline serves four kinds of decisions namely decision planning, formation decisions, implementation decisions, playback decisions. Evaluators and Evaluators must play a key role in all aspects of evaluative information within an organization in building results capacity, in managing evaluative knowledge systems, and in creating evaluative information and knowledge, including through the implementation of evaluation studies [17].

\section{RESULTS AND DISCUSSIONS}

\subsection{Context Evaluation}

The components that are the focus of research in the evaluation of the context of the implementation of curriculum 2013 are: government policy /education unit policy (school), school vision-mission and curriculum objectives, school work program plan. The implementation of the 2013 curriculum is the implication of central government policy through the Ministry of Education and Culture which took the decision to change the 2006 curriculum to curriculum 2013 through Permendikbud No. 81 A on the implementation of the 2013 curriculum in elementary schools (MI/elementary schools), junior high schools/MTs, high schools/ma, and vocational schools? MAK in the 2013/2014 school year. As one of the schools appointed by the Ministry of Religion in Mampang Prapatan area, there is certainly no other option except to implement the 2013 Curriculum with the potential and resources it has.

\subsection{Input evaluation}

Aspects of educators and educational personnel. As a technical implementer of the curriculum in the classroom, the understanding of teachers about curriculum 2013 can be categorized quite well. There are only a few obstacles where the condition of educators is $45 \%$ over 50 years old, so it takes quite a while to be able to adapt to the curriculum changes and understand well the implementation of curriculum 2013. In addition to the age factor, their educational background is also one of the factors that became an obstacle in the implemnetization of curriculum 2013. The number of teachers who are not from PGSD/PGMI courses so their knowledge is minimal in relation to materials as classroom teachers. Education and training are still considered less done given the condition of teachers who are far from well understood category about curriculum 2013. Some teachers are not familiar with IT, so their way of teaching still hasn't moved on in the traditional way. Asnana said rusman and lukman in his journal that teachers occupy a strategic position in the successful development and implementation of curriculum 2013.

\subsection{Aspects of Madrasah Facilities and Infrastructure}

MI Al Khairiyah Pagi has good and adequate facilities and infrastructure. Physical facilities such as a three-storey madrassa building equipped with classroom facilities with projector and CCTV, library room, 
laboratory room, SS room, teacher's room, sports field, prayer room. But for learning media is still not ideal and still needs to be improved again. There is also a need for facilities for teachers to prepare learning administration. The readiness of facilities and infrastructure in the implementation of curriculum 2013 will be very supportive of learning. [18]

\subsection{Evaluation of Curriculum Implementation Process 2013}

Related to the implementation of learning, the application of integrative thematic learning is one of the components of the process that is discussed by the evaluation findings in this study. Based on the results of interviews and observations in the field shows that the teachers have carried out integrative thematic learning but not yet fully. The lack of deeper teacher understanding of the 2013 Curriculum is an obstacle in implementing it. In addition, there is still no change in the mindset within teachers in addressing curriculum changes. However, there are some teachers who are enthusiastic and strive to make the most of the thematic reciprocity. Of course, all happens because of several causative factors such as, the background of education that is not appropriate, the age that has been less productive again so reluctant to create. For teachers who apply integrative thematic also have obstacles in the field such as lack of time duration and also the capacity of students who exceed the capacity of the ideal number of students in the classroom. The lack of time duration is felt because the allocation of lesson hours for thematic teaching has not been in accordance with the established standards. The madrassa had to divide the clock with local load subjects that were quite crowded. As a result, the duration of thematic learning becomes reduced, which ultimately results in remedial implementation and enrichment becoming un optimal.

In addition to integrative thematic learning, the application of GLS in MI Al Khairiyah varies. In addition to reading, the movement of habituation of solat duha and tadarus moments before KBM was included in the school literacy program. based on observations and interview results, the application of school literacy movement for habituation duha and tadarus runs very well, only for literacy reading still can not run optimally because the time available is very minimal. Thus it can be concluded that in the process components of the implementation aspect of learning especially seen in terms of the implementation of GLS in MI Al Khairiyah Pagi has not been effective. The last process in the implementation of learning is the assessment of students' learning. MI Al Khairiyah Pagi has formally implemented a learning assessment (authentic assessment) complete with its description.
But practically and substantively the teacher's assessment of his students is more likely to be his knowledge assessment alone. For skill assessment, teachers take grades from a child's work from a worksheet they have. Many teachers do not yet understand the preparation of instruments and rubrics required in skill assessment. In the end, the teacher gives a mature grade or final grade only without looking at the process.

\subsection{Product Evaluation of Curriculum Implementation 2013 at MI Al Khairiyah Pagi}

Based on the data in the field gathered from the results of interviews and observations shows that the achievements of $\mathrm{mi}$ al Khairiyah Pagi students, especially in the academic field showed quite good results, namely in 2018/2019 the average value of USBN for three subjects, namely: Bahasa Indonesia, Mathematics, and IPA reached 68.80 while for the $2019 / 2020$ study year the average score of 70.24 Based on the data, the average score obtained by students was not at a satisfactory stage.

However, for each year, students of MI Al Khairiyah Pagi can complete and finish their studies by graduating $100 \%$. Non-academically, mi al khairiyah pagi students have the achievement of winning the silat competition at South Jakarta level which is 1st and 2nd place. Tahfiz's achievements were also rejected by the students by winning the tahfiz level of Mampang Prapatan SubDistrict. The other non-academic achievement category is reflected in the habituation of islamic character values applied in MI Al Khairiyah Pagi. This can be seen from the habituation of the order before the start of KBM, the habituation of Duha Prayer, zuhur prayer and ashar congregation already looks good.

Judging from the educator aspect, the phenomenon of change can be seen from the habits of teachers who in the previous time (when KTSP curriculum) was not familiar with IT, then nowadays with the implementation of Curriculum 2013 became brave to try and get used to IT. In addition, teachers who used to walk alone in the KBM process, are now accustomed to discussing with colleagues about the learning that will be done. They share knowledge, share experiences, and coordinate with each other for technical uniformity in material delivery. In the product component was found results that showed that the implementation of curriculum 2013 in MI Al Khairiyah Pagi had a positive impact on the development of potential students and teachers. 


\subsection{Blocking Factor of Curriculum Implementation 2013 in MI Al Khairiyah Pagi Kendala from the government}

Late distribution of student books and teacher books. The delay occurred during the first and second year of the implementation of curriculum 2013 and at the time of the change in Core Competency and Basic Competency in 2016. Socialization of implementation, training / training / bimtek from the education office is not maximal. The large number of learning administrations that teachers have to work on causes teachers to no longer have more time to upgrade their abilities and competencies. Integrative thematic application with a scientific approach. This implementation requires extensive knowledge, as well as being active and creative in designing, drafting, designing, and implementing the 2013 Curriculum. Therefore, bimtek, training / training must continue to be pursued by the government and institutions / schools. Constraints stemming from teachers

There are still some teachers who are in the comfort zone, are reluctant to make changes and tend to stick with the old pattern. This can be seen from the tendency of some teachers who have not implemented changes in the learning process from teacher centered to student centered. The level of teacher mastery of IT is still low, as well as the application of synthetic learning that has not been mastered by the teacher. Teachers still have difficulty making assessment instruments and rubrics, so they tend to emphasize the cognitive aspects of the assessment. Teachers are still having trouble preparing HOTS-based questions.

\subsection{Constraints that come from institutions}

The foundation's intervention is almost inevitable. It is not even uncommon for the chairman of the foundation to be the principal. MI Al Khairiyah Pagi is one of the schools whose management implementation is centralistic (centralized in the foundation). Although each institution is authorized to organize and manage the school, the policy is not separated from the foundation's intervention. The limited school budget in implementing the implementation of curriculum 2013 clearly has an impact on the effectiveness and success of educational institutions in implementing school work programs. financing restrictions are due to the madrassa still concentrating on the construction of additional buildings. Another obstacle at the school management level is in terms of the preparation of school curriculum documents that are still dominated by curriculum representatives. Included in determining the structure of the school curriculum.

\subsection{Obstacles that come from students and parents.}

The obstacles encountered from the students aspect are still low literacy rates among students. The input of students of diverse backgrounds, cognitive levels, and motivational levels influences the motivation and learning success of students.

In addition to the obstacles that come from the students, other obstacles also arise from the parents of the students. Attitudes and tendencies of parents of students who have not been active and participatory in supporting the implementation of curriculum 2013 in MI Al Khairiyah Pagi is still the number of parents who do not monitor their child's development do not attend the invitation of the meeting held by the madrassa

\section{CONCLUSIONS, IMPLICATIONS, AND RECOMMENDATIONS}

Based on the results of data analysis in this study on the evaluation of the implementation of curriculum 2013 cipp theory perspective (context, input, process, product) in MI Al Khairiyah Pagi Mampang Prapatan South Jakarta can be summed up as follows:

\subsection{Conclusion}

\subsubsection{Context evaluation}

The school's policy in implementing the 2013 Curriculum was legalized in the form of school curriculum documents validated by the principal, committee, supervisor, and Head of Field (Kabid) of South Jakarta Elementary School Development. The document outlines the guidelines and programs of school work in carrying out school activities (including curriculum programs) within the next year.

School vision, mission, objectives, and programs

Based on the results of data analysis can be concluded that the vision, mission, objectives, and school work program in MI Al Khairiyah Pagi Mampang Prapatan has been very good and contributed enough to the implementation of curriculum 2013 in MI Al Khairiyah Pagi Mampang Prapatan.

\subsubsection{Input evaluation}

Aspects of educators and educational personnel. In general, teachers at MI Al Khairiyah Pagi Mampang Prapatan understand the concept of Curriculum 2013. As a pilot project school in the implementation of curriculum 2013, almost all teachers have already participated in training / training except for new 
teachers. For the size of the target schools in the implementation of curriculum 2013, bimtek or training for educators / teachers in MI Al Khairiyah Pagi Mampang Prapatan is still not enough, especially the assistance of educators or coaching from the education office which is only done about 2-4 times a year.

Learner aspect. From the results of the data analysis can be concluded that in the input component, in general it appears that students in MI Al Khairiyah Pagi Mampang Prapatan are quite effective in supporting the implementation of curriculum 2013. However, there are still some students who tend to be passive. Input of students of diverse backgrounds, cognition levels, and motivations including students with special needs is one of the obstacles.

Aspects of school infrastructure

Based on the analysis of data can be concluded that in the input component of the aspects of facilities and infrastructure, especially student books and teacher handbooks have been effective and contributive in supporting the implementation of curriculum 2013 in MI Al Khairiyah Pagi Mampang Prapatan.

\subsubsection{Evaluation process}

All teachers at MI Al Khairiyah Pagi Mampang Prapatan have devised learning devices (syllabus, RPP, prosem, and prota), but in the implementation of the learning process there are still some teachers who still have difficulty in applying thematic learning with the famous scientific approach $5 \mathrm{M}$, namely: observing, questioning, trying/collecting information/ experiments, associating/processing information, and communicating. Another difficulty experienced by some teachers is in compiling instruments and rubric scoring as well as the preparation of hot skill-based questions. In addition, the implementation of the School Literacy Movement (GLS) has also not been in accordance with the procedure.

\subsubsection{Product evaluation}

In the product component was found results that showed that the implementation of curriculum 2013 in MI Al Khairiyah Pagi Mampang Prapatan had a positive impact on the development of potential students and teachers.

\subsection{Implications}

\subsubsection{Improvement efforts rather than context aspects}

The school curriculum document which is a reference/guideline in carrying out learning activities in schools in the next year should be compiled jointly by involving teachers, principals, supervisors and school committees and socializing them to all school residents so that all parties have a comprehensive understanding of the 2013 Curriculum as well as being responsible in supporting and implementing curriculum 2013 in MI Al Khairiyah Pagi Mampang Prapatan.

\subsubsection{Improvement efforts from the input aspect}

To increase success in the implementation of curriculum 2013 in MI Al Khairiyah Pagi Mampang Prapatan, it is necessary to improve efforts from all aspects, both in terms of Human Resources, education especially teachers, student input (by facilitating companion teachers and shadow teachers), infrastructure facilities such as the procurement of books and supporting learning media, as well as improvements in the aspect of funding or financing.

\subsubsection{Improvement efforts from the process aspect}

The improvement efforts to solve the problem are by strengthening the scientific approach of teachers through $\mathrm{KKG}$ in one cluster, sharing process with peers, sharing between peers, and training or mentoring educators.

Product improvement efforts

In general, the implication of the implementation of curriculum 2013 in MI Al Khairiyah Pagi Mampang Prapatan is to make students and teachers more active, creative, and innovative in carrying out the learning process. The implications of all that the school must facilitate teachers and students to develop its potential with all its consequences and budget.

\subsection{Recommendations}

\subsubsection{Context Evaluation}

Although the school curriculum documents of each school (including MI Al Khairiyah Pagi Mampang Prapatan) are different because they are adapted to the vision, mission, and characteristics of each school, but in its preparation (including the curriculum structure) must still refer to the National Curriculum Document and Structure which is based on Permendikbud No. 81A of 2013 and Permendikbud No. 57 of 2014.

\subsubsection{Input Evaluation}

In the input component, it is recommended for the school to increase the participation and 
participation/cooperation of all school stakeholders, be it the principal, teachers and their staff and employees, parents of students, school committees, and education services to support, socialize and implement the 2013 Curriculum in MI Al Khairiyah Pagi Mampang Prapatan more optimally, namely through the utilization of educational resources (budget, infrastructure, educators and education) owned.

\subsubsection{Evaluation Process}

In the process component, the school is recommended to improve the implementation management of curriculum 2013 from the aspect of the learning implementation process namely through: 1 . Conduct training motivation every 1-2 months; 2 . Conduct training, workshop or sharing with teachers in the school environment and carried out continuously; 3 . Teachers must be active in participating in KKG activities organized by the group; 4 . The principal together with the foundation to form a R\&D unit of the Foundation to reformulate the policy because it has a great impact on the successful implementation of curriculum 2013 at MI Al Khairiyah Pagi Mampang Prapatan; 5. Supervise the implementation of curriculum 2013 so that the implementation process can be more optimal.

\subsubsection{Product Evaluation}

Based on the conclusions and implications of the research, the implementation of curriculum 2013 in MI Al Khairiyah Pagi Mampang Prapatan is recommended to continue to improve the quality of education in accordance with the objectives of national education based on the prevailing laws and regulations and adapted to the vision, mission, and characteristics, specifications or characteristics of each school.

\section{ACKNOWLEDGMENTS}

Thanks to the Postgraduate School of Muhammadiyah University Prof. DR. HAMKA who has provided full support in the production of this article

\section{REFERENCES}

[1] Zaenal Arifin, Curriculum Development Concepts and Models. Bandung: PT. Teen Rosdakarya Offset. 2013.

[2] Majid, A. Implementation of Curriculum 2013 Theoretical and Practical Studies. Bandung: Interes Media. 2014.
[3] Bazalgette, C. Introduction. In C. Bazalgette (Ed.), Teaching media in primary schools (pp. 111). London, England: Sage. 2010.

[4] Frau-Meigs, D., Velez, I., \& Michel, J. F. (Eds.). (2017). Public policies in media and information literacy in Europe. Abingdon, England: Routledge.

[5] Jenkins, H. Convergence culture: Where old and new media collide. New York, NY: New York University Press. 2006.

[6] van Deursen, A. J. A. M., Helsper, E. J., \& Eynon, R. Development and validation of the internet skills scale (ISS). Information, Communication \& Society, 2015. 19(6), 804823.

https://doi.org/10.1080/1369118X.2015.1078834

[7] Zhou, H. T. Studies on university curriculum. Beijing: China Social Sciences Press In Chinese. 2008.

[8] Zhou, H. Y. Empirical study on university curriculum satisfaction of university graduates. Open Journal of Social Sciences, 4, 2016. 132137.

[9] Zhong, Q. Q. Curriculum theory. Beijing: Educational Science Publishing House In Chinese. 2007.

[10] Miao, M. Evaluation study on undergraduate course in higher education (master dissertation). Shanghai: East China Normal University In Chinese. 2007

[11] Diamond, R. M. Designing and assessing courses and curricula: A practical guide, 3rd ed. San Francisco: John Wiley \& Sons. 2008.

[12] Hamalik, Oemar, Curriculum Development Management, Bandung : PT. Rosdakarya's teenager. 2013

[13] Regulation of the Minister of Education and Culture No. 67/2013 on elementary school curriculum. Jakarta: Ministry of Education and Culture.

[14] Moleong, Lexy J. Qualitative Penenlitian Methodology, Jakarta: PT Remaja Rosdakarya. 2014.

[15] Dwi Muryadi, Agustanico Model Evaluasi Program dalam Penelitian Evaluasi. Jurnal Ilmiah PENJAS, Vol.3, No.1. 2017.

[16] Sukardi, Evaluation of Education, Principles and Operations, Jakarta: Bumi Aksara. 2009.

[17] Mayne, John \& Rist, R. Studies are not enough: The necessary transformation of evaluation. Canadian Journal of Program Evaluation. 21. 93120. 2006.

[18] Sri Budiani et al.. Evaluation of Curriculum Implementation 2013 in Independent Implementing School 2016. 